\title{
SKIRTINGŲ KINEZITERAPIJOS METODŲ EFEKTYVUMAS SKOLIOZE SERGANČIŲ JAUNŲ ŽMONIŲ STUBURO PARAMETRAMS IR PARASPINALINIŲ RAUMENU TONUSUI
}

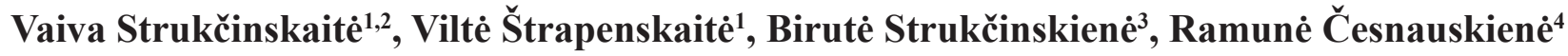 \\ ${ }^{1}$ Vilniaus universiteto Medicinos fakulteto Sveikatos mokslu institutas, \\ ${ }^{2}$ Vilniaus kolegijos Sveikatos priežiūros fakulteto Reabilitacijos katedra, \\ ${ }^{3}$ Klaipédos universiteto Sveikatos mokslu fakultetas, \\ ${ }^{4}$ Kauno kolegijos Medicinos fakultetas
}

Raktažodžiai: idiopatinė skoliozè, specialioji kineziterapija, Schroth metodas, liemens stabilizavimo pratimai, paraspinaliniai raumenys, DIERS 3D, jauni žmonès.

\section{Santrauka}

Šiomis dienomis taikomi ịvairūs konservatyvūs jaunatvine idiopatine skolioze sergančių pacientų kineziterapinio gydymo būdai, tačiau nèra bendros nuomonès, kuris metodas yra naudingiausias. Lietuvoje specialioji kineziterapija, kuriai priskiriamos kelios skirtingos metodikos, pradèta taikyti prieš penkerius metus, bet tyrimų, lyginančių simetrinių bei asimetrinių pratimų taikymo efektyvumą, nebuvo daryta. Darbo tikslas - ịvertinti skirtingų kineziterapijos metodų efektyvumą sergančiųjų idiopatine skolioze stuburo parametrams ir paraspinalinių raumenų tonusui. Tyrimas atliktas Vilniaus miesto asmens sveikatos priežiūros įstaigoje. Tyrime dalyvavo $16(n=16)$ 10-16 metų tiriamujų, sergančių jaunatvine idiopatine skolioze. Tiriamieji buvo suskirstyti ị dvi eksperimentines grupes: I grupei $(\mathrm{n}=8)$ buvo taikoma specialioji kineziterapija Schroth metodu, II grupei $(n=8)$ - liemens stabilizavimo pratimai. Iš viso buvo atlikta 10 kineziterapijos procedūrų. Tyrime taikyta DIERS 3D sistema stuburo parametrų ištyrimui ir neinvazinis miotonometras „Myoton - 3“ raumenų tonusui matuoti. Testavimai atlikti prieš ir po reabilitacijos. Statistinè duomenu analizė atlikta naudojant R 3.6.1 paketą ir MS Excel programą. Duomenys vertinami kaip statistiškai reikšmingi, kai $p<0,05$. Atlikus duomenų analizę nustatyta, kad lyginant DIERS 3D sistema gautus rezultatus tarp grupių, specialioji kineziterapija reikšmingiau sumažino tiriamujų paviršiaus rotacijos laipsnị $(p=0,021)$, liemens stabilizavimo pratimai - dubens pakrypimo įverti ( $2 \mathrm{~mm}$ mažiau) $(\mathrm{p}<0,05)$. Krūtininis kifozinis kampas abiejose grupėse po reabilitacijos nereikšmingai padidejo, artėjo prie normų, tačiau jų neatitiko. Analizuojant tiriamujų paraspinalinių raumenų tonusą, lyginant vidutinius pokyčius tarp grupių, natūralių virpesių dažnio rodiklis kairèje pusėje ties L5 slanksteliu raumens įtampos metu labiau kito II grupèje, kurioje sumažèjo, o I grupèje padidèjo $(p<0,05)$. Slopinimo parametro rodikliai po reabilitacijos buvo mažesni I grupejje. Tyrimo rezultatai atskleidè, kad specialioji kineziterapija efektyvesnè, mažinant paviršiaus rotacijos laipsni, o liemens raumenų stabilizavimo pratimai - dubens pakrypimo vertinimo rodikli. Specialiosios kineziterapijos taikymas reikšmingiau padidino natūralių virpesių dažnio rodiklį kairèje pusèje ties L5 slanksteliu raumens įtampos metu, - tai rode nežymiai didesnę tiriamujų paraspinalinių raumenų jègą nei liemens stabilizavimo pratimų grupejje; sumažino slopinimo rodiklio rezultatus po reabilitacijos, - tai rodè didesni paraspinalinių raumenų elastingumą.

\section{İvadas}

Skoliozè - sudètingas trimatis (frontalioje, sagitalioje ir horizontalioje plokštumose) stuburo iškrypimas, kuriam būdingas bent 10 laipsnių pagal Cobb kampą šoninis slankstelių nuokrypis kartu su slankstelių rotacija apie savo aši [1]. Skoliozè gali būti diagnozuojama visais amžiaus tarpsniais, tačiau labiausiai paplitusi yra jaunatvinè idiopatinè skoliozè, būdinga 1-4 proc. paauglių nuo 10 iki 18 metu $[2,3]$. Nustatyta, kad skoliozè dažniau diagnozuojama mergaitems (mergaičiu ir berniukų santykis svyruoja nuo 1,5:1 iki 3:1). Amžiaus didejjimas koreliuoja su santykio tarp lyčių didejjimu, t. y. vyresnių paauglių mergaičiu procentiškai yra daugiau, nei paauglių berniukų [1]. Progresavimas yra ženkliai didesnis tarp mergaičių: nedidelio iškrypimo (10$20^{\circ}$ ) santykis tarp lyčių beveik nesiskiria (mergaitès $1,3: 1$ 
berniukai), 20-30 iškrypimo santykis yra 5,4:1, o didžiausio laipsnio iškrypimas (per $30^{\circ}$ ) berniukams pasitaiko labai retai $(7: 1)$ [4]. Idiopatinè skoliozè, jos atsiradimo priežastys ir progresavimo metu vykstantys ịvairūs pakitimai yra aktualios temos gydytojams ir reabilitacijos specialistams, nes skoliozė sukelia laikysenos ir stuburo parametrų pokyčius bei paraspinalinių raumenų biomechanikos pakitimus igaubtoje ir išgaubtoje stuburo pusèse [5]. Tokią deformaciją turintiems paaugliams frontalioje plokštumoje yra būdingas šoninis stuburo nukrypimas, dubens pakrypimas ir liemens disbalansas, horizontalioje plokštumoje idiopatinei skoliozei būdinga slankstelių rotacija, o sagitalioje stuburo parametrų pokyčiai priklauso nuo kreivès viršūnès lokalizacijos. Be šių stuburo parametrų pokyčių, idiopatinès skoliozès atveju pakinta paraspinalinių raumenų funkcija. Paraspinaliniai raumenys ypač svarbūs juosmenineje stuburo dalyje ir turi dvi funkcijas - atlieka liemens judesius ir išlaiko kūno stabilumą judesio metu [6]. Esant jaunatvinei idiopatinei skoliozei, ypač jai progresuojant, vienas svarbiausių pokyčių yra liemens raumenų disbalansas, kurio priežastis - pakitusi paraspinalinių raumenų funkcija dèl stuburo deformacijos [7]. Dèl šių priežasčių gydymas yra labai svarbus ir vienas pagrindinių jo tikslų - sustabdyti arba sumažinti progresavimą, kuris didžiausias būna paauglių (ypač mergaičių) augimo metu, ir palaikyti mažesni nei $50^{\circ}$ iškrypimą pagal Cobb kampą [8]. Pagal pasaulines rekomendacijas, 10-25 laipsnių idiopatinè skoliozė gydoma taikant specifinę kineziterapiją, 25-50 laipsnių - dèvint liemens ịtvarą-korsetą ir taikant specifinę kineziterapiją, >50 laipsnių - operaciniu būdu [4].

Specialioji kineziterapija susideda iš individualiai pritaikytų pratimų, atsižvelgiant ị paciento stuburo iškrypimą bei fizinę būklę, o jos principai yra autokorekcija, stuburo ilginimas, individualus paciento mokymas ir pratimų ịtraukimas ị kasdienes ịprastines veiklas [9]. Pasaulyje žinoma keletas idiopatinès skoliozès gydymo specialiosios kineziterapijos metodikų, tačiau daugiausia ištirtas ir praktikuojamas yra Schroth metodas - taikomi specialūs individualiai parinkti pratimai, rotacinė kvėpavimo technika, akcentuojant ịkvėpimą i ịgaubtają kreivès zoną, ir ypač svarbi laikysenos hiperkorekcija [10]. Naujausi tyrimai apie Schroth metodo efektyvumą parodè, kad tai tinkamas ir naudingas konservatyvus būdas mažinti stuburo iškrypimo Cobb kampą bei gerinti gyvenimo kokybę [11]. Dar vienas efektyvus skoliozės gydymo metodas yra liemens stabilizavimo pratimai, kurie veikia paraspinalinius raumenis, o pagrindinis šio metodo aspektas yra giliujų liemens raumenų aktyvinimas, kontroliuojant liemens padètį ne tik statinèse padètyse, bet ir funkcinių judesių bei veiklų metu [12]. Idiopatinès skoliozès atveju būdingas šių raumenų jègos mažèjimas, sukeliantis stuburo nestabilumą, tad pacientams svarbu taikyti liemens stabilizavimo pratimų programą, kad būtų didinama raumenų jèga, stuburo stabilumas bei laikysenos kontrolè statinių ir dinaminių pratimų metu [13].

Darbo tikslas - ivertinti skirtingų kineziterapijos metodų efektyvumą skolioze sergančių jaunų žmonių stuburo parametrams ir paraspinalinių raumenų tonusui.

\section{Tyrimo medžiaga ir metodai}

Tyrimas atliktas Vilniaus miesto asmens sveikatos priežiūros įstaigoje. Iš viso tyrime dalyvavo $16(n=16)$ tiriamųų, sergančių jaunatvine idiopatine skolioze. Amžius - 10-16 metų. Tiriamieji buvo suskirstyti ị dvi eksperimentines grupes: I grupei $(n=8)$ taikyta specialioji kineziterapija Schroth metodu, II grupei $(\mathrm{n}=8)$ - liemens stabilizavimo pratimai. Iš viso atlikta 10 kineziterapijos procedūrų, 5 kartus per savaitę po 30 minučių. Tyrime taikyta DIERS 3D sistema stuburo parametrų ištyrimui ir neinvazinis miotonometras „Myoton - 3“ raumenų tonusui matuoti. Testavimai atlikti prieš ir po reabilitacijos. Statistinè duomenų analizè atlikta naudojant $\mathrm{R}$ programos 3.6.1 duomenų analizès paketą ir MS Excel programą. Duomenys vertinami kaip statistiškai reikšmingi, kai $\mathrm{p}<0,05$.

\section{Tyrimo rezultatai ir jų aptarimas}

Stuburo parametrų vertinimas atliktas naudojant DIERS 3D diagnostinį tyrimo metodą. Sia sistema tyrimo metu buvo testuoti 7 stuburo parametrai trijose plokštumose: liemens disbalansas ( $\mathrm{mm}$ ), dubens pakrypimas ( $\mathrm{mm}$ ), dubens pasisukimas $\left({ }^{0}\right)$, paviršiaus rotacija $\left({ }^{0}\right)$, šoninis nukrypimas $(\mathrm{mm})$ ir pagrindinius natūralius stuburo linkius apibūdinantys parametrai - kifozinis $\left({ }^{0}\right)$ ir lordozinis $\left({ }^{0}\right)$ kampai. Analizuojant rezultatus I ir II eksperimentinių grupių viduje, statistiškai reikšmingai pagerèjo tik I eksperimentinèje grupejje vieno parametro rezultatas - paviršiaus rotacijos laipsnis, kurio vidutinis rezultatas sumažejo nuo $8,3 \pm 3,6$ laipsnių (prieš reabilitaciją) iki 6,5 $\pm 2,9$ laipsnių po reabilitacijos $(\mathrm{p}=0,031)$ (1 lentelè). Šioje grupejje po reabilitacijos teigiamai pakito liemens disbalanso $(\mathrm{mm})$, dubens pasisukimo $\left({ }^{\circ}\right)$, šoninio nukrypimo $(\mathrm{mm})$ ir kifozinio kampo $\left({ }^{\circ}\right)$ parametrai, tačiau tai nesudare statistiškai reikšmingų skirtumų. Analizuojant stuburo linkių kampų padidejjimą, tai buvo vertinama kaip teigiamas pokytis, nors kifozinis kampas po reabilitacijos normų nepasiekè. Dubens pakrypimo $(\mathrm{mm})$ vidutinès reikšmès padidèjimas nuo $3,9 \pm 1,6 \mathrm{~mm}$ iki $4,8 \pm 2,7 \mathrm{~mm}$ buvo vertinamas kaip neigiamas pokytis.

II eksperimentinejje grupejje statistiškai reikšmingų skirtumų nenustatyta $(\mathrm{p}>0,05)$. Keleto parametrų vidutinès vertès po reabilitacijos mažėjo: liemens disbalanso (nuo $7,9 \pm 4,8 \mathrm{~mm}$ prieš iki $6,4 \pm 5,3 \mathrm{~mm}$ po reabilitacijos), dubens 
1 lentelè. I grupés DIERS 3D stuburo parametrų rezultatai prieš ir po reabilitacijos ${ }^{*} p<0,05$

\begin{tabular}{|c|c|c|c|c|c|c|c|c|c|}
\hline \multirow{2}{*}{$\begin{array}{l}\text { DIERS 3D } \\
\text { parametrai }\end{array}$} & \multicolumn{4}{|c|}{ Prieš reabilitaciją } & \multicolumn{4}{|c|}{ Po reabilitacijos } & \multirow[b]{2}{*}{$\underset{\text { reikšmė }}{p}$} \\
\hline & $\begin{array}{l}\text { vidur- } \\
\text { kis }\end{array}$ & SN & $\min$ & $\max$ & $\begin{array}{l}\text { vidur- } \\
\text { kis }\end{array}$ & SN & $\min$ & $\max$ & \\
\hline $\begin{array}{l}\text { Liemens disba- } \\
\text { lansas }(\mathrm{mm})\end{array}$ & 8,4 & 5,5 & 0 & 16 & 7,8 & 5,5 & 0 & 15 & 0,608 \\
\hline $\begin{array}{l}\text { Dubens pakry- } \\
\text { pimas (mm) }\end{array}$ & 3,9 & 1,6 & 3 & 7 & 4,8 & 2,7 & 3 & 10 & 0,371 \\
\hline $\begin{array}{l}\text { Dubens pasisu- } \\
\text { kimas }\left({ }^{0}\right)\end{array}$ & 3,6 & 3,1 & 0 & 8 & 2,9 & 1,9 & 1 & 7 & 0,605 \\
\hline $\begin{array}{l}\text { Paviršiaus } \\
\text { rotacija }\left({ }^{0}\right)\end{array}$ & 8,3 & 3,6 & 4 & 14 & 6,5 & 2,9 & 3 & 12 & $0,031 *$ \\
\hline $\begin{array}{l}\text { Šoninis nukry- } \\
\text { pimas }(\mathrm{mm})\end{array}$ & 10,0 & 7,9 & 2 & 22 & 8,4 & 5,7 & 4 & 17 & 0,172 \\
\hline $\begin{array}{l}\text { Kifozinis } \\
\text { kampas } \\
\left(\max ,{ }^{0}\right)\end{array}$ & 41,9 & 9,8 & 30 & 58 & 43,8 & 5,9 & 36 & 55 & 0,305 \\
\hline $\begin{array}{l}\text { Lordozinis } \\
\text { kampas } \\
\left(\max ,{ }^{0}\right)\end{array}$ & 40,9 & 7,8 & 33 & 53 & 41,5 & 6,5 & 32 & 52 & 0,625 \\
\hline
\end{tabular}

2 lentelė. DIERS 3D stuburo parametrų vidutiniai pokyčiai ${ }^{*} p<0,05$

\begin{tabular}{|l|c|c|c|}
\hline DIERS 3D parametrai & $\begin{array}{c}\text { I eksperimen- } \\
\text { tinès grupés } \\
\text { pokytis }\end{array}$ & $\begin{array}{c}\text { II eksperimen- } \\
\text { tinès grupés } \\
\text { pokytis }\end{array}$ & p reikšmė \\
\hline Liemens disbalansas $(\mathrm{mm})$ & $-0,6 \pm 3,3$ & $-1,5 \pm 3,2$ & 0,596 \\
\hline Dubens pakrypimas $(\mathrm{mm})$ & $0,9 \pm 1,6$ & $-2,0 \pm 2,1$ & $\mathbf{0 , 0 1 6}$ \\
\hline Dubens pasisukimas $\left(^{*}\right)$ & $-0,8 \pm 2,5$ & $0,3 \pm 0,9$ & 0,642 \\
\hline Paviršiaus rotacija $\left({ }^{0}\right)$ & $-1,8 \pm 1,8$ & $0,5 \pm 1,6$ & $\mathbf{0 , 0 2 1}{ }^{*}$ \\
\hline Šoninis nukrypimas $(\mathrm{mm})$ & $-1,6 \pm 2,9$ & $-0,4 \pm 1,6$ & 0,301 \\
\hline Kifozinis kampas $\left(\mathrm{max}^{0}{ }^{0}\right)$ & $1,9 \pm 4,8$ & $2,6 \pm 3,2$ & 0,718 \\
\hline Lordozinis kampas $\left.{ }^{*}{ }^{0}\right)$ & $0,6 \pm 3,5$ & $2,3 \pm 3,5$ & 0,363 \\
\hline
\end{tabular}

3 lentelè. I grupès natūralių virpesių dažnio rodikliai prieš ir po reabilitacijos Ats. - atsipalaidavęs raumuo; $[s$. - isitempęs raumuo ${ }^{*} p<0,05$

\begin{tabular}{|c|c|c|c|c|c|c|c|c|c|}
\hline \multirow{3}{*}{$\begin{array}{l}\text { Raumenų } \\
\text { tonusas }\end{array}$} & \multicolumn{8}{|c|}{ Natūralių virpesių dažnis (Hz) } & \multirow{3}{*}{$\begin{array}{c}\mathbf{p} \\
\text { reikš- } \\
\text { mé }\end{array}$} \\
\hline & \multicolumn{4}{|c|}{ prieš reabilitaciją } & \multicolumn{4}{|c|}{ po reabilitacijos } & \\
\hline & $\begin{array}{c}\text { vidur- } \\
\text { kis }\end{array}$ & SN & $\min$ & $\max$ & $\begin{array}{c}\text { vidur- } \\
\text { kis }\end{array}$ & SN & $\min$ & $\max$ & \\
\hline Ats., dešinè, L1 & 16,1 & 3,5 & 12,7 & 24,3 & 15,2 & 2,7 & 12,2 & 21,3 & $\mathbf{0 , 0 3 9} *$ \\
\hline Ats., dešinè, L5 & 14,5 & 2,7 & 11,8 & 20,6 & 13,8 & 1,7 & 11,1 & 15,7 & 0,674 \\
\hline Ats., kairè, L1 & 15,5 & 4,7 & 11,8 & 26,7 & 14,6 & 2,1 & 11,7 & 18,3 & 0,547 \\
\hline Ats., kairè, L5 & 13,9 & 2,5 & 11,3 & 19,4 & 14,0 & 2,6 & 11,0 & 19,2 & 1 \\
\hline İs., dešinè, L1 & 26,6 & 3,2 & 20,9 & 31,4 & 26,7 & 4,2 & 21,3 & 35,5 & 0,825 \\
\hline Is., dešinè, L5 & 23,5 & 3,8 & 17,9 & 30,1 & 23,2 & 3,3 & 18,3 & 28,7 & 0,457 \\
\hline Iss., kairè, L1 & 26,3 & 3,3 & 20,5 & 30,5 & 25,4 & 3,7 & 18,3 & 30,0 & 0,051 \\
\hline Is., kairè, L5 & 21,5 & 5,8 & 15,5 & 29,9 & 22,1 & 5,1 & 13,8 & 30,0 & 0,489 \\
\hline
\end{tabular}

pakrypimo (nuo $12,5 \pm 19,1 \mathrm{~mm}$ prieš iki $10,5 \pm 17,4 \mathrm{~mm}$ po) bei šoninio nukrypimo (nuo $7,0 \pm 6,5 \mathrm{~mm}$ prieš iki $6,6 \pm 5,7 \mathrm{~mm}$ po) (1 pav.).

II grupeje buvo fiksuoti trys parametru rodikliai, kurių vidutinès vertès padidejo: kifozinis bei lordozinis kampai $\left({ }^{\circ}\right)$ bei paviršiaus rotacija $\left({ }^{0}\right)$. I grupeje pastarojo parametro vidutinè reikšmẻ sumažèjo, o II grupejje buvo stebimas vidutinio rezultato padidèjimas nuo 4,6 2,8 laipsnių

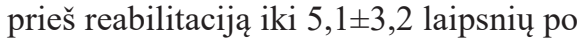
reabilitacijos. Stuburo linkių vidutiniai rezultatai, kaip ir I grupeje, padidejo ir nors vidutinès reikšmés pokytis II grupeje po reabilitacijos buvo didesnis, nei I grupejje (kifozinis kampas padidèjo nuo 37,6 $11,7^{0}$ iki $40,3 \pm 9,4^{0}$, lordozinis kampas - nuo $38,3 \pm 8,8^{0}$ iki $40,5 \pm 7,3^{\circ}$ ). Galutinis rezultatas - šios grupès stuburo linkiai buvo mažesni, nei I grupès, kifozinis kampas neatitiko normu $\left(47-50^{\circ}\right)$, o rezultatai nebuvo statistiškai reikšmingi $(\mathrm{p}>0,05)$.

Analizuojant DIERS 3D stuburo parametrų vidutinius pokyčius tarp grupių, statistiškai reikšmingai skyrèsi dubens pakrypimo $(\mathrm{mm})$ bei paviršiaus rotacijos $\left(^{\circ}\right)$ parametrai, $\mathrm{p}<0,05$ (2 lentelè), (2 pav.). Pirmojo parametro vidurkis po reabilitacijos I grupejje didejo (pokytis $0,9 \pm 1,6 \mathrm{~mm}$ ), II grupejje - mažejo (pokytis $-2,0 \pm 2,1 \mathrm{~mm})$. Paviršiaus rotacijos $\left({ }^{0}\right)$ vidurkis I grupeje, priešingai, sumažèjo (pokytis $-1,8 \pm 1,8^{0}$ ), o II grupeje - padidèjo (pokytis $0,5 \pm 1,6^{0}$ ).

Dubens pakrypimo vidutinio rezultato padidejjimas antrojo testavimo metu buvo vertinamas kaip neigiamas pokytis, nes tai rode, jog I grupès tiriamujų dubens pakrypimas padidejo, t. y. padidejjo aukščio skirtumas tarp kryžkaulio duobučių kairejje ir dešinèje pusèse. Paviršiaus rotacijos vidutinès vertès sumažèjimas I grupejje rodè teigiamą pokytị, nes šis parametras yra siejamas su stuburo iškrypimo laipsniu pagal Cobb kampą. I grupès ištirtų mergaičių su idiopatine skolioze paviršiaus rotacija statistiškai reikšmingai labiau mažèjo, lyginant su II grupe. Taigi, specialioji kineziterapija efektyvi mažinant paviršiaus rotacijos laipsni. 
Tyrimo metu buvo testuojami trys pagrindiniai paraspinalinių raumenų tonuso parametrai: natūralių virpesių dažnis (angl. frequency), slopinimas (angl. decrement) ir standumas (angl. stiffness). Nagrinejant rezultatus I ir II eksperimentinių grupių viduje, buvo stebimi tik vieno parametro - natūralių virpesių dažnio statistiškai reikšmingi skirtumai. Šis parametras I grupejje reikšmingai pakito ties vienu rodikliu - dešinèje puseje ties L1 slanksteliu raumens atsipalaidavimo metu, $p<0,05$. Prieš reabilitaciją rodiklio vidurkis buvo $16,1 \pm 3,5 \mathrm{~Hz}$, o po reabilitacijos stebimas sumažèjimas iki 15,2 $\pm 2,7 \mathrm{~Hz}$ (3 lentelè).

II eksperimentinèje grupejje pastebèti dviejų natūralių virpesių dažnio rodiklių statistiškai reikšmingi pokyčiai $(p<0,05)$ : dešinejje puseje ties L1 slanksteliu raumens atsipalaidavimo metu bei kaireje puseje ties L5 slanksteliu raumens įtampos metu. Pirmojo rodiklio prieš reabilitaciją fiksuotas vidutinis rezultatas buvo $15,1 \pm 2,7 \mathrm{~Hz}$, po $-14,2 \pm 2,5 \mathrm{~Hz}$, antrojo rodiklio vidurkis prieš reabilitaciją $22,6 \pm 3,1 \mathrm{~Hz}$, o po

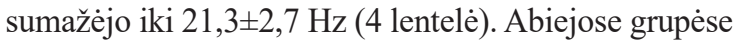
didžiausios vidutinès reikšmès buvo užfiksuotos prieš ir po reabilitacijos to paties rodiklio - dešinejje pusejje ties L1 slanksteliu raumens įtampos metu. I grupejje ši vertè svyravo nuo $26,6 \pm 3,2 \mathrm{~Hz}$ prieš iki $26,7 \pm 4,2$ $\mathrm{Hz}$ po reabilitacijos. II eksperimentinèje grupèje šio rodiklio vidutinès vertès buvo šiek tiek mažesnès, tačiau bendroje lentelèje tai žymėjo didžiausią vidurkį: $23,6 \pm 3,7 \mathrm{~Hz}$ prieš ir $24,1 \pm 3,5 \mathrm{~Hz}$ po reabilitacijos (3 ir 4 lentelès).

Tyrimo pabaigoje gautų paraspinalinių raumenų tonuso natūralių virpesių dažnio rodiklių vidutiniški pokyčiai I ir II eksperimentinèse grupèse pateikti 5 lentelèje. Daugelyje rodiklių tiek I, tiek II grupejje buvo fiksuotos sumažèjusios vidutinès vertès, išskyrus šiuos rodiklius: I grupejje kaireje pusejje ties L5 slanksteliu raumens atsipalaidavimo metu $(0,0 \pm 0,7 \mathrm{~Hz})$; abiejose grupèse dešinèje pusėje ties L1 slanksteliu raumens itampos metu (I grupé $0,1 \pm 1,7 \mathrm{~Hz}$, II grupè $0,5 \pm 1,3 \mathrm{~Hz}$ ) bei I grupejje kairèje pusejje ties L5 slanksteliu raumens ittampos metu $(0,6 \pm 2,2 \mathrm{~Hz})$. Statistiškai reikšmingas skirtumas tarp grupių buvo nustatytas tik pastarojo rodiklio ( $\mathrm{p}=0,041)$, kadangi II eksperimentinejje grupeje fiksuotas minusinis pokytis $(-1,3 \pm 1,1 \mathrm{~Hz})$, I grupejje - teigiamas pokytis $(0,6 \pm 2,2)$. Tai rodè, kad II grupès tiriamujjų kairèje apatinèje nugaros dalyje paraspinaliniai raumenys įsitempimo metu

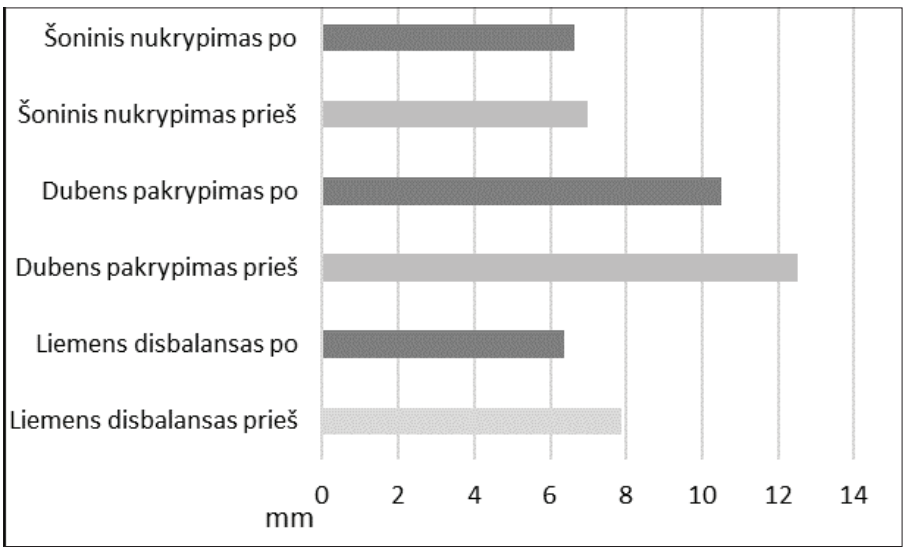

1 pav. II grupės DIERS 3D stuburo parametrų rezultatai prieš ir po reabilitacijos

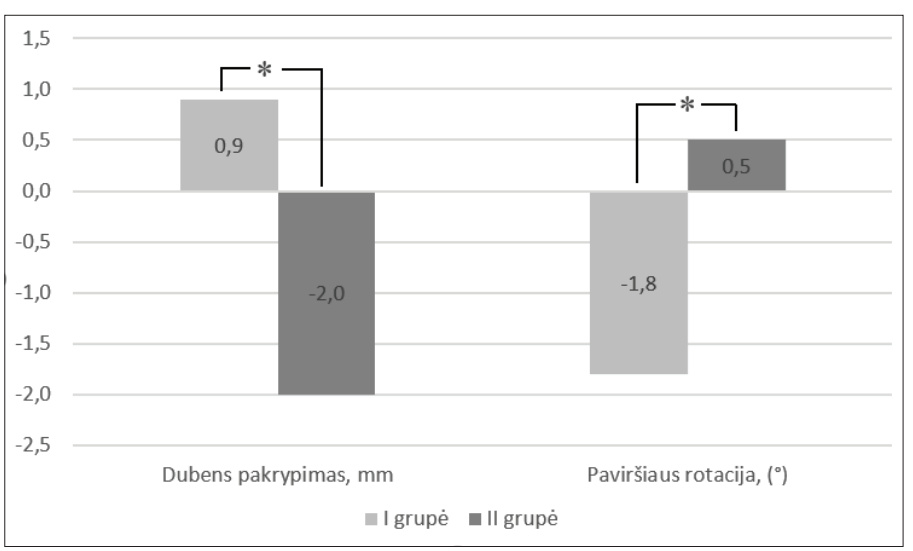

2 pav. Dubens pakrypimo ir paviršiaus rotacijos rezultatų pokyčiai tarp grupių

${ }^{*} p<0,05$
4 lentelè. II grupès natūralių virpesių dažnio rodikliai prieš ir po reabilitacijos Ats. - atsipalaidavęs raumuo; İs. - įsitempęs raumuo ${ }^{*} p<0,05$

\begin{tabular}{|c|c|c|c|c|c|c|c|c|c|}
\hline \multirow{3}{*}{$\begin{array}{l}\text { Raumenų } \\
\text { tonusas }\end{array}$} & \multicolumn{8}{|c|}{ Natūralių virpesių dažnis $(\mathrm{Hz})$} & \multirow{3}{*}{$\begin{array}{c}\mathbf{p} \\
\text { reikš- } \\
\text { mé }\end{array}$} \\
\hline & \multicolumn{4}{|c|}{ prieš reabilitaciją } & \multicolumn{4}{|c|}{ po reabilitacijos } & \\
\hline & $\begin{array}{c}\text { vidur- } \\
\text { kis }\end{array}$ & SN & $\min$ & $\max$ & $\begin{array}{c}\text { vidur- } \\
\text { kis }\end{array}$ & SN & $\min$ & $\max$ & \\
\hline Ats., dešinè, L1 & 15,1 & 2,7 & 11,5 & 20,3 & 14,2 & 2,5 & 10,2 & 18,2 & $0,014 *$ \\
\hline Ats., dešinè, L5 & 12,9 & 1,8 & 10,6 & 15,2 & 12,6 & 1,8 & 10,3 & 15,1 & 0,058 \\
\hline Ats., kairè, L1 & 14,3 & 3,1 & 11,3 & 21 & 13,7 & 2,2 & 11,4 & 18,2 & 0,141 \\
\hline Ats., kairè, L5 & 14,3 & 2,0 & 11,1 & 18,2 & 13,9 & 1,2 & 12,4 & 15,5 & 0,485 \\
\hline İs., dešinè, L1 & 23,6 & 3,7 & 19,2 & 28,3 & 24,1 & 3,5 & 20,4 & 22,0 & 0,370 \\
\hline Is., dešinè, L5 & 20,9 & 5,3 & 12,2 & 31,7 & 20,4 & 4,6 & 12,2 & 28,9 & 0,309 \\
\hline Iss., kairé, L1 & 21,7 & 3,7 & 15,9 & 27,4 & 21,4 & 3,6 & 14,4 & 26,2 & 0,525 \\
\hline Is., kairè, L5 & 22,6 & 3,1 & 17,9 & 25,8 & 21,3 & 2,7 & 18,0 & 15,3 & $0,011 *$ \\
\hline
\end{tabular}


5 lentelè. Natūralių virpesių dažnio rodiklių vidutiniai pokyčiai Ats. - atsipalaidavęs raumuo; $[s$. - įsitempęs raumuo ${ }^{*} p<0,05$

\begin{tabular}{|c|c|c|c|}
\hline \multirow[b]{2}{*}{$\begin{array}{l}\text { Raumenų } \\
\text { tonusas }\end{array}$} & \multicolumn{2}{|c|}{ Natūralių virpesių dažnis $(\mathrm{Hz})$} & \multirow[b]{2}{*}{ p reikšmė } \\
\hline & $\begin{array}{c}\text { I eksperimen- } \\
\text { tinès grupès } \\
\text { pokytis }\end{array}$ & $\begin{array}{c}\text { II eksperimen- } \\
\text { tinės grupės } \\
\text { pokytis }\end{array}$ & \\
\hline Ats., dešinè, L1 & $-0,9 \pm 1,1$ & $-0,9 \pm 0,8$ & 0,939 \\
\hline Ats., dešinè, L5 & $-0,7 \pm 1,9$ & $-0,3 \pm 0,4$ & 0,501 \\
\hline Ats., kairè, L1 & $-0,1 \pm 3,2$ & $-0,6 \pm 1,0$ & 0,463 \\
\hline Ats., kairè, L5 & $0,0 \pm 0,7$ & $-0,34 \pm 1,3$ & 0,497 \\
\hline İs., dešinè, L1 & $0,1 \pm 1,7$ & $0,5 \pm 1,3$ & 0,687 \\
\hline Is., dešinè, L5 & $-0,3 \pm 1,1$ & $-0,5 \pm 1,3$ & 0,737 \\
\hline İs., kairè, L1 & $-0,9 \pm 1,1$ & $-0,3 \pm 1,1$ & 0,253 \\
\hline İs., kairè, L5 & $0,6 \pm 2,2$ & $-1,3 \pm 1,1$ & $0,041 *$ \\
\hline
\end{tabular}

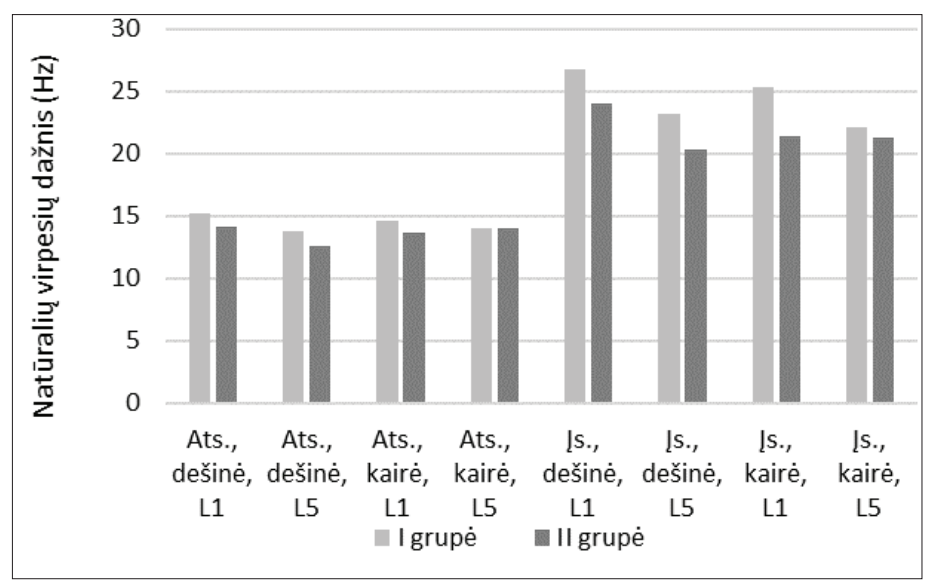

3 pav. Natūralių virpesių dažnio rodiklių rezultatai po reabilitacijos Ats. - atsipalaidavęs raumuo; Is. - isitempęs raumuo.

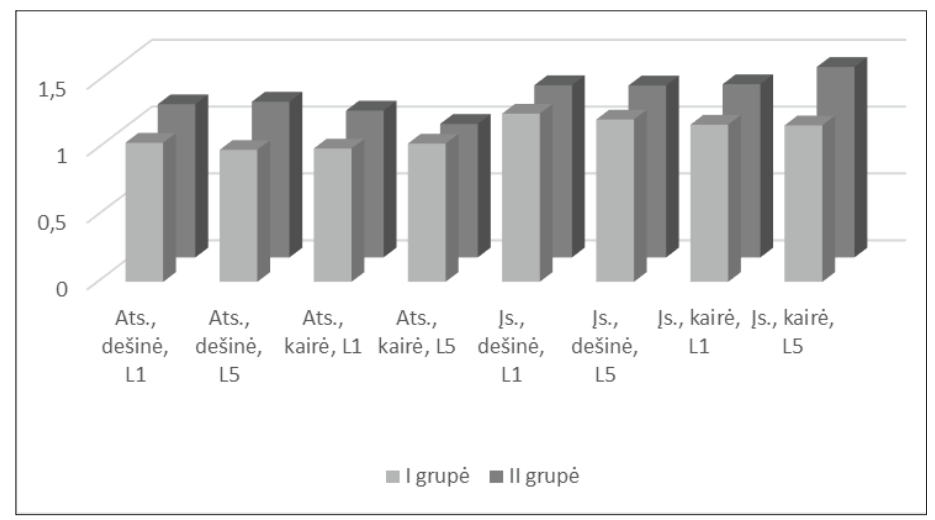

4 pav. Slopinimo rodiklių rezultatai po reabilitacijos Ats. - atsipalaidavęs raumuo; Is. - įsitempęs raumuo. po reabilitacijos pasižymėjo šiek tiek mažesne jèga, kadangi raumens įtampos metu šis parametras rodo raumens jègą.

Esant normaliam raumens funkcionavimui, įtampos metu reikšmès turi pakilti nuo 18 iki $40 \mathrm{~Hz}$, tad abiejose grupèse šis pakilimas buvo pastebètas tiek prieš, tiek ir po reabilitacijos. Po reabilitacijos abiejose grupèse buvo pastebèti nereikšmingai didesni natūralių virpesių dažnio rodiklių vidutiniai rezultatai viršutinèje (ties L1 slanksteliu) juosmens dalyje, nei apatinèje (ties L5 slanksteliu) (4 pav.). Ties L1 ir L5 slanksteliais įsitempusio raumens natūralių virpesių dažnio rodikliai buvo nežymiai didesni pirmoje grupeje (3 pav.).

Slopinimo ir standumo rodiklių rezultatų vidutiniški pokyčiai tarp grupių statistiškai reikšmingai nesiskyrè. Mažesnès slopinimo rodiklių vidutinès vertès po reabilitacijos buvo fiksuotos I eksperimentinejje grupejje, o tai rodè, kad šioje grupeje tiriamujų paraspinalinių raumenų elastingumas buvo didesnis, nes mažesnè reikšmė reiškia didesnị raumens elastingumą (4 pav.). Nagrinejjant standumo rodiklius, abiejų grupių rezultatai atitiko normas - ramybès metu normos neviršijo $300 \mathrm{~N} / \mathrm{m}$, įsitempimo metu neviršijo 1000 N/m [14].

Šiomis dienomis reabilitacijoje taikomi ịvairūs konservatyvūs jaunatvinès idiopatinès skoliozès gydymo būdai, tačiau, nors atliekama daug mokslinių tyrimų, reabilitacijos specialistai neprieina prie bendros nuomonès, kuris iš metodu yra efektyviausias. Mūsų tyrimo tikslas buvo ịvertinti skirtingų kineziterapijos metodų efektyvumą stuburo parametrams bei paraspinalinių raumenų tonusui.

Siekiant detaliau analizuoti skirtingų tiriamiesiems taikytų metodų efektyvumą, kaip pagrindinè tyrimo priemonė buvo naudojamas DIERS 3D paviršinès topografijos principu veikiantis diagnostinis irenginys. DIERS 3D sistema yra atlikta tyrimų, kurių metu buvo matuoti ir lyginami rezultatai prieš ir po reabilitacijos taikant specialiają kineziterapiją, o tyrimų pabaigoje buvo fiksuotas paviršiaus rotacijos laipsnio sumažejimas [15,16], kas buvo stebèta ir mūsų tyrimo pabaigoje. Mūsų tyrimo trūkumas ir skirtumas, lyginant su kitais moksliniais tyrimais, yra reabilitacijos trukmé - šių mokslininkų atliktuose tyrimuose pratimu programa buvo taikyta 4-6 savaites, o mūsų tyrime - 2 savaites. N. Pugachevos tyrime [15] be paviršiaus rotacijos laipsnio sumažèjimo, kaip ir mūsų tyrime, buvo stebimas teigiamas pacienčių kifozinio kampo padidejjimas 
po antrojo testavimo. Pagal kitų mokslinių tyrimų gaires, Schroth metodas yra plačiausiai taikomas iš visų specialiosios kineziterapijos metodų ir yra efektyvus, mažinant skoliozès sukeltas deformacijas, iškrypimo laipsni pagal Cobb bei gerinant gyvenimo kokybę $[9,17]$.

Liemens stabilizavimo pratimų programa, mokslinių tyrimų išvadomis, taip pat yra efektyvus būdas mažinant skoliozės iškrypimo laipsni pagal Cobb kampą, skausmą, liemens deformacijas ir didinant liemens raumenų jègą $[12,13]$. Mūsų tyrime DIERS 3D diagnostiniu tyrimu II grupeje buvo fiksuotas tik vieno parametro - dubens pakrypimo - statistiškai reikšmingas vidutinès reikšmès sumažejjimas po reabilitacijos. Paviršiaus rotacijos laipsnis, kuris atitinka Cobb kampą, šioje grupeje po reabilitacijos nežymiai padidejo, tačiau daugumoje atliktų mokslinių tyrimų, kuriuose gautas statistiškai reikšmingas Cobb kampo sumažèjimas, reabilitacijos programa buvo taikyta ženkliai ilgiau (10-12 savaičių), nei mūsų tyrime (2 savaitės).

Analizuojant skoliozę turinčių asmenų paraspinalinių raumenų tonusą, mūsų tyrime, kaip ir kituose [19-20], šiek tiek didesni visi rodikliai buvo fiksuoti išgaubtoje kreivès puseje, išskyrus standumo rodikli raumens atsipalaidavimo metu. $2018 \mathrm{~m}$. atlikto tyrimo metu, kaip ir mūsų tyrime, viršutinèje nugaros dalyje ties L1 slanksteliu natūralių virpesių dažnio rodikliai buvo didesni, nei apatineje dalyje ties L5 slanksteliu. Mokslinių tyrimų duomenimis, viena iš priežasčiu gali būti anatominių paraspinalinių raumenų savybių skirtumas šiose vietose - viršutinejje dalyje raumenys yra arčiau paviršiaus, o apatinejje dalyje raumenị dengia storesnis minkštujų audinių sluoksnis, todèl tonuso parametrai gali būti mažiau tikslūs [21]. Tyrimo metu buvo testuojami trys pagrindiniai paraspinalinių raumenų tonuso parametrai: natūralių virpesių dažnis, slopinimas ir standumas. Šiame tyrime buvo gautas vienas statistiškai reikšmingas skirtumas - natūralių virpesių dažnio, kuris nurodo raumens įtampą, rodiklis ties L5 slanksteliu kairejje pusèje raumens įsitempimo metu II grupejje sumažejo $(-1,3 \pm 1,1 \mathrm{~Hz})$, o I grupejje padidejo $(0,6 \pm 2,2 \mathrm{~Hz})$. Tai rodè, kad II grupés tiriamujų kaireje apatinejje nugaros dalyje paraspinaliniai raumenys ịsitempimo metu po reabilitacijos pasižymejjo šiek tiek mažesne jèga, kadangi raumens ịtampos metu šis parametras nurodo raumens jègą. Slopinimo parametro, kaip Y. Liu ir kt. [5] bei A. Pan ir kt. [22] tyrimu rezultatuose, statistiškai reikšmingo skirtumo tarp stuburo pusių nebuvo, tačiau po reabilitacijos mažesni rodikliai buvo I grupejje. Šis parametras yra atvirkščiai proporcingas raumens elastingumui, todèl kuo reikšmè mažesnè, tuo raumuo pasižymi didesniu elastingumu. Mūsų tyrime specialiosios kineziterapijos eksperimentineje grupeje po reabilitacijos paraspinalinių raumenų elastingumas buvo didesnis, nei II grupès, kuriai buvo taikyti liemens stabilizavimo pratimai.
Nagrinèjant standumo rodiklius, abiejų grupių rezultatai atitiko normas - ramybès metu normos neviršijo $300 \mathrm{~N} / \mathrm{m}$, ìsitempimo metu neviršijo 1000 N/m [14].

Apibendrinant galima teigti, kad parenkant kineziterapijos metodą pacientui, sergančiam idiopatine skolioze, itin svarbi yra reabilitacijos trukmè ir stuburo iškrypimo laipsnis. Abu šiame tyrime taikyti metodai - specialioji kineziterapija ir liemens stabilizavimo pratimai turi būti taikomi ilgesnị laiką, norint pasiekti statistiškai reikšmingų skoliozès sukeltų stuburo parametrų pakitimų, Cobb kampo sumažejmo ir paraspinalinių raumenų funkcijų pagerẻjimo. Mūsų tyrimas atskleide, kad Schroth metodas efektyviai sumažina paviršiaus rotacijos laipsnị, tad turi teigiamos įtakos skoliozès progresavimo prevencijai, taip pat, šis metodas turejo įtakos palaikant paraspinalinių raumenų jègą ir elastingumą. Liemens stabilizavimo pratimai efektyvūs mažinant idiopatine skolioze sergančių asmenų dubens pakrypimą.

\section{Išvados}

1. Analizuojant I ir II grupių stuburo parametrų vidutinius pokyčius, I grupejje reikšmingiau sumažejo paviršiaus rotacijos laipsnis, II grupejje - dubens pakrypimo vertinimo rodiklis $(p<0,05)$. Krūtininis kifozinis kampas nereikšmingai padidejjo abiejose grupèse, artejo prie normų, tačiau po reabilitacijos jų neatitiko ( $>0,05)$.

2. Lyginant abiejų eksperimentinių grupių paraspinalinių raumenų tonuso rezultatų vidutinius pokyčius, natūralių virpesių dažnio rodiklis kairejje pusẻje ties L5 slanksteliu raumens įtampos metu labiau kito II grupeje, kurioje sumažèjo, o I grupèje padidejo $(\mathrm{p}<0,05)$. Slopinimo rodikliai po reabilitacijos buvo mažesni I grupèje.

3. Tyrimo rezultatai atskleide, kad specialioji kineziterapija efektyvesnè mažinant paviršiaus rotacijos laipsni, o liemens raumenų stabilizavimo pratimai - dubens pakrypimo vertinimo rodikli. Specialiosios kineziterapijos taikymas reikšmingiau padidino natūralių virpesių dažnio rodiklį kairèje pusèje ties L5 slanksteliu raumens įtampos metu, - tai rodė nežymiai didesnę tiriamųjų paraspinalinių raumenų jëgą, nei liemens stabilizavimo pratimų grupejje; sumažino slopinimo rodiklio rezultatus po reabilitacijos, rodančius didesnị paraspinalinių raumenų elastingumą.

\section{Literatūra}

1. Choudhry MN, Ahmad Z, Verma R. Adolescent idiopathic scoliosis. Open Orthop J 2016;10(1):143-54. https://doi.org/10.2174/1874325001610010143

2. Alves DPL, De Araújo B. Muscle disorders in adolescent idiopathic scoliosis: literature review. Columna 2016;15(1):73-7. https://doi.org/10.1590/S1808-185120161501151839

3. Wong AYL, Samartzis D, Cheung PWH, Yin Cheung JP. How 
common is back pain and what biopsychosocial factors are associated with back pain in patients with adolescent idiopathic sco-liosis? Clin Orthop Relat Res 2019;477(4):676-86.

https://doi.org/10.1097/CORR.0000000000000569

4. Negrini S, Aulisa AG, Aulisa L, Circo AB, de Mauroy JC, Durmala J, et al. 2011 SOSORT guidelines: orthopaedic and rehabilitation treatment of idiopathic scoliosis during growth. Sco-liosis 2012;7(1).

https://doi.org/10.1186/1748-7161-7-3

5. Liu Y, Pan A, Hai Y, Li W, Yin L, Guo R. Asymmetric biomechanical characteristics of the paravertebral muscle in adolescent idiopathic scoliosis. Clin Biomech 2019;65:81-6.

https://doi.org/10.1016/j.clinbiomech.2019.03.013

6. Wang CK, Fang YHD, Lin LC, Lin CF, Kuo LC, Chiu FM, et al. Magnetic resonance elastogra-phy in the assessment of acute effects of kinesio taping on lumbar paraspinal muscles. J Magn Reson Imaging 2019;49(4):1039-45.

https://doi.org/10.1002/jmri.26281

7. Modi HN, Suh SW, Yang JH, Hong JY, Venkatesh KP, Muzaffar N. Spontaneous regression of curve in immature idiopathic scoliosis - does spinal column play a role to balance? An observa-tion with literature review. J Orthop Surg Res 2010;5(1):80. https://doi.org/10.1186/1749-799X-5-80

8. Lotan S, Kalichman L. Manual therapy treatment for adolescent idiopathic scoliosis. J Bodyw Mov Ther 2019;23(1):189-93. https://doi.org/10.1016/j.jbmt.2018.01.005

9. Berdishevsky H, Lebel VA, Bettany-Saltikov J, Rigo M, Lebel A, Hennes A, et al. Physiothera-py scoliosis-specific exercises - a comprehensive review of seven major schools. Scoliosis Spinal Disord 2016;11(1):1-52.

https://doi.org/10.1186/s13013-016-0076-9

10. Aly MIE, Amin FS, Negm MA, Attyah A, Diab M. Effect of integrated exercise program on posture in adolescent idiopathic scoliosis (case study). J Adv Pharm Educ Res 2019;9(S2):169-72.

11. Burger M, Coetzee W, du Plessis LZ, Geldenhuys L, Joubert F, Myburgh E, et al. The effective-ness of schroth exercises in adolescents with idiopathic scoliosis: a systematic review and meta-analysis. South African J Physiother 2019;75(1):904. https://doi.org/10.4102/sajp.v75i1.904

12. Gür G, Ayhan C, Yakut Y. The effectiveness of core stabilization exercise in adolescent idiopa-thic scoliosis: a randomized controlled trial. Prosthet Orthot Int 2017;41(3):303-10. https://doi.org/10.1177/0309364616664151

13. Ko KJ, Kang SJ. Effects of 12-week core stabilization exercise on the Cobb angle and lumbar muscle strength of adolescents with idiopathic scoliosis. J Exerc Rehabil 2017;13(2):244-9. https://doi.org/10.12965/jer.1734952.476

14. Chuang LL, Wu CY, Lin KC, Lur SY. Quantitative mechanical properties of the relaxed biceps and triceps brachii muscles in patients with subacute stroke: a reliability study of the Myoton-3 myometer. Stroke Res Treat 2012; article ID 617694. https://doi.org/10.1155/2012/617694

15. Pugacheva N. Corrective exercises in multimodality therapy of idiopathic scoliosis in children-analysis of six weeks efficiency-pilot study. Stud Health Technol Inform 2012;176:365-71.

16. Jelačić M, Villagrasa M, Pou E, Quera-Salvá G, Rigo M. Barcelona scoliosis physical therapy school-BSPTS-based on classical Schroth principles: short term effects on back asymmetry in idiopathic scoliosis. Scoliosis 2012;7(1):1.

https://doi.org/10.1186/1748-7161-7-S1-O57

17. Zmyślna A, Kiebzak W, Żurawski A, Pogorzelska J, Kotela I, Kowalski TJ, et al. Effect of physiotherapy on spinal alignment in children with postural defects. Int J Occup Med Environ Health 2019;32(1):25-32.

https://doi.org/10.13075/ijomeh.1896.01314

18. Chwaba W, Koziana A, Kasperczyk T, Walaszek R, Pbaszewski M. Electromyographic assessment of functional symmetry of paraspinal muscles during static exercises in adolescents with idiopathic scoliosis. BioMed Res Int 2014; 2014:573276.

https://doi.org/10.1155/2014/573276

19. Rusovs G, Vetra A. Convex side muscular activity and progression of scoliotic curve. Scoliosis 2010;5(S1):O23.

https://doi.org/10.1186/1748-7161-5-S1-O23

20. Kwok G, Yip J, Cheung MC, Yick KL. Evaluation of myoelectric activity of paraspinal muscles in adolescents with idiopathic scoliosis during habitual standing and sitting. Biomed Res Int 2015,958450.

https://doi.org/10.1155/2015/958450

21. Hu X, Lieberman IH. Prevalence and factors affecting cervical deformity in adolescent idiopathic scoliosis patients: a single-center retrospective radiological study. Int J Spine Surg 2018;12(1):22-5.

https://doi.org/10.14444/5004

22. Pan A, Hai Y, Liu Y, Zhang Y, Zhang L, Li W, et al. Assessment of biomechanical properties of paraspinal muscles in adolescent idiopathic scoliosis. Natl Med J China 2018;98(43):3485-9.

\section{THE EFFECT OF DIFFERENT PHYSIOTHERAPY METHODS ON SPINAL PARAMETERS AND PARASPINAL MUSCLES TONE IN YOUNG PEOPLE WITH SCOLIOSIS}

V. Strukčinskaitė, V. Štrapenskaitė, B. Strukčinskienė, R. Česnauskienè

Keywords: idiopathic scoliosis, scoliosis - specific exercises (PSSE), Schroth method, core stabilization exercises, paraspinal muscles, DIERS 3D, young people.

Summary

Nowadays, varieties of conservative physiotherapy treatments are used for patients with adolescent idiopathic scoliosis, but there is no consensus on which method is most beneficial. In Lithuania, special physiotherapy, which includes several different methodologies, was introduced five years ago and no studies comparing the effectiveness of symmetrical and asymmetrical exercises have 
been performed. The aim of this study was to evaluate the effect of different physiotherapy methods on spinal parameters and paraspinal muscles tone in patients with idiopathic scoliosis. The study was conducted in Vilnius city health care institution. The study included $16(\mathrm{n}=16)$ subjects aged $10-16$ years with adolescent idiopathic scoliosis. The patients were divided into two experimental groups. Scoliosis - specific exercises for group I and core stabilization exercises for group II was used. For patients were applied 10 procedures of physiotherapy. The DIERS 3D system for measuring spinal parameters and myotonometer ,Myoton - 3 ” for measuring muscle tone were used in the study.

Data analysis showed that special physiotherapy using Schroth method significantly reduced the degree of surface rotation of the subjects $(\mathrm{p}=0.021)$, and core stabilization exercises significantly reduced pelvic tilt $(2 \mathrm{~mm}$ less $)(\mathrm{p}<0.05)$. The thoracic kyphosis angle in both groups increased insignificantly after rehabilitation, approaching the norms, but did not meet them. When analyzing the tone of the examined paraspinal muscles, the indicator of the parameter "frequency" on the left side at the L5 vertebra during mus- cle tension changed more in group II, where it decreased, while in group I increased $(\mathrm{p}<0.05)$. The , decrement" parameters after rehabilitation were lower in group I. The results of the study revealed that special physiotherapy is more effective in reducing the degree of surface rotation, and core stabilization exercises are more effectice in reducing pelvic tilt. The use of special physiotherapy significantly increased the results of "frequency" on the left side at the L5 vertebra during muscle tension, which showed a slightly higher strength of the studied paraspinal muscles than in the core stabilization exercise group; and reduced the results of the "decrement" index after rehabilitation, which showed greater elasticity of the paraspinal muscles.

Correspondence to: vaiva.struk@gmail.com

Gauta 2020-09-08

\section{KVIEČIAME PRENUMERUOTI „SVEIKATOS MOKSLŲ“ ŽURNALĄ 2021 METAIS!}

Žurnalas „Sveikatos mokslai“ (Index Copernicus, EBSCO host (Academic Search Complete), Gale (Academic OneFile), ProQuest (Ulrich's, Summon), Australia (ERA) 2012 Journal List (ERA ID 34962) skirtas visų specialybių gydytojams, slaugytojams ir kitiems specialistams, spausdina mokslinius straipsnius lietuvių, anglų kalbomis. Reikalavimai straipsniams atitinka mokslo leidiniams keliamus reikalavimus. Žurnalas kioskuose neparduodamas. Žurnalą, kuris leidžiamas kartą per du mènesius, galima užsiprenumeruoti visuose Lietuvos pašto skyriuose, taip pat internetu: www.prenumeruok.It

Prenumeratos kaina nesikeičia: visiems metams - 36 EUR, šešiems mėnesiams - 18 EUR, keturiems mėnesiams - 12 EUR, dviem mėnesiams - 6 EUR. Prenumeratos kodas: 5348.

Žurnalo autoriams straipsnių spausdinimas mokamas.

Redakcija 